\section{In Vitro Rooting and Greenhouse Acclimatization of Veltheimia bracteata and $V$. capensis Shoots}

\author{
James R. Ault ${ }^{1}$ \\ Department of Horticulture, Longwood Gardens, P.O. Box 501, Kennett \\ Square, PA 19348
}

Additional index words. bush lily, forest lily, sand lily, micropropagation, tissue culture

\begin{abstract}
Shoot initiation and multiplication were obtained in vitro from immature flower bud and leaf explants of Veltheimia bracteata Bak. 'Lemon Flame' and from leaf explants of $V$. bracteata 'Rosalba' cultured on a Murashige and Skoog (MS) medium supplemented with sucrose at $30 \mathrm{~g} \cdot \mathrm{L}^{-1}$, and either $8.87 \mu_{\mathrm{M}}$ BA plus $0.54 \mu_{\mathrm{M}} \mathrm{NAA}$ or $8.87 \mu_{\mathrm{M}}$ BA plus 5.40 $\mu_{M}$ NAA. Shoot initiation and multiplication was obtained from a single leaf explant of Veltheimia capensis (L.) DC. on MS medium with $8.87 \mu \mathrm{M}$ BA plus $0.54 \mu \mathrm{M}$ NAA. Shoots of the three genotypes rooted on subculture to medium with $0.0,4.14$, or $8.29 \mu_{\mathrm{M}} \mathrm{K}$-IBA or $0.0,4.46$, or $8.92 \mu_{\mathrm{M}} \mathrm{K}$-NAA. Maximal rooting was $98 \%$ for $V$. bracteata 'Lemon Flame', $95 \%$ for $V$. bracteata 'Rosalba', and $98 \%$ for $V$. capensis, from medium with $4.46 \mu \mathrm{M} \mathrm{K}$ NAA. Rooted shoots were acclimatized for 3 to 4 weeks. Overall survival percentage was 69\% for $V$. bracteata 'Lemon Flame', $65 \%$ for $V$. bracteata 'Rosalba', and $83 \%$ for $V$. capensis. Chemical names used: 6-benzyladenine (BA); potassium salt of indole-3-butyric acid (K-IBA); potassium salt of 1-naphthaleneacetic acid (K-NAA); 1-naphthaleneacetic acid (NAA).
\end{abstract}

Veltheimia bracteata, the bush or forest lily, and $V$. capensis, the sand lily, are ornamental species of the Hyacinthaceae native to southern Africa (Du Plessis and Duncan, 1989). These bulbous plants are winter-growing, summer-dormant, and are not frost-tolerant. They are ideal greenhouse and home-window plants. They are 1) easy to cultivate, 2) pest-free, and 3) remain in flower for up to 6 weeks in winter and early spring. The attractive leaves have undulating margins and the racemes bear numerous cylindrical, pendulous flowers in shades of pink or chartreuse (Du Plessis and Duncan, 1989).

Veltheimias are propagated from seed or offsets; however, plants from seed take 3 or more years to flower (Du Plessis and Duncan, 1989), and offsets are slow to form (Doutt, 1994). Veltheimia bracteata is extremely variable in flower color (Du Plessis and Duncan, 1989). The superior forms should be vegetatively propagated for extensive horticultural use, but due to the propagation difficulties, selected clones are not readily available commercially. Tissue culture propagation could be a method of clonally increasing selected forms of these species. The objective of this study was to develop a protocol for shoot initiation, multiplication and rooting, and greenhouse acclimatization of tissue-culture propagated plants of $V$. bracteata 'Lemon Flame', V. bracteata 'Rosalba', and a compact form of $V$. capensis (received as $V$. capensis

Received for publication 16 Jan. 1996. Accepted for publication 30 Aug. 1996. The cost of publishing this paper was defrayed in part by the payment of page charges. Under postal regulations, this paper therefore must be hereby marked advertisement solely to indicate this fact.

${ }^{1}$ Current address: Chicago Botanic Garden, 1000 Lake Cook Rd., Glencoe, IL 60022. var. deasii). To my knowledge, no other published report exists on the tissue-culture propagation of these plants. However, other geophyte species of the Hyacinthaceae have been tissue-culture propagated, including Eucomis (Ault, 1995), Galtonia (Drewes and van Staden, 1993), Hyacinthus (Hussey, 1975), and Lachenalia (Ault, 1995; Nel, 1983).

\section{Materials and Methods}

Plants of $V$. bracteata 'Lemon Flame' were obtained from a commercial nursery and from Kirstenbosch Botanical Garden in South Africa in 1986. Plants of $V$. bracteata 'Rosalba' were obtained from a commercial nursery in New Zealand in 1991. Plants of V. capensis were donated to Longwood Gardens in 1987. Five or fewer plants of each genotype were available for propagation at the initiation of this study. To avoid sacrificing plants, bulb tissue was not used for explants; instead, leaf tissue of all three genotypes and immature flower buds of $V$. bracteata 'Lemon Flame' were used as explants. Similar techniques were used for Lachenalia, a related genus from South Africa that has been tissue-culture propagated from leaf tissue (Ault, 1995; Klesser and

Leaves were excised between Nov. 1992 and Mar. 1993 from the bulbs of greenhousegrown plants. Leaves of Veltheimia are borne on the above-ground portion of a partially subterranean-growing bulb. The individual plants were vegetative to $\approx 50 \%$ into floral anthesis at the time of leaf removal. One leaf per plant was removed. The proximal onethird of each leaf $(\approx 10$ to $15 \mathrm{~cm} \times 15$ to $20 \mathrm{~cm}$ for $V$. bracteata and 2 to $4 \mathrm{~cm} \times 3$ to $5 \mathrm{~cm}$ for $V$. capensis) was rinsed in running tap water for $5 \mathrm{~min}$, surface-disinfected in a continuNel, 1976; Nel, 1983). ously stirred solution of $1.0 \%$ sodium hypochlorite and $0.1 \%$ Tween 20 for $12 \mathrm{~min}$, and rinsed once in sterile distilled water for 5 to 10 min. Individual leaf explants, each $5 \times 10 \mathrm{~mm}$, were placed horizontally, abaxial side down, in $25 \times 150-\mathrm{mm}$ culture tubes containing 10 $\mathrm{mL}$ of medium. Medium consisted of MS (Murashige and Skoog, 1962) basal salts and vitamins, sucrose at $30 \mathrm{~g} \cdot \mathrm{L}^{-1}$, and either no plant growth regulators (PGRs) or the combinations of $4.44 \mu \mathrm{M}$ BA or $8.87 \mu \mathrm{M}$ BA with $0.54 \mu \mathrm{m}$ NAA or $5.4 \mu \mathrm{M}$ NAA. Medium $\mathrm{pH}$ was adjusted to 5.7 before adding agar at $7 \mathrm{~g} \cdot \mathrm{L}^{-1}$ (Sigma A 1296, Sigma Chemical Co., St. Louis). Culture tubes were sealed with polypropylene caps and autoclaved at $121^{\circ} \mathrm{C}$ for 15 min.

After explant placement, culture tubes were sealed with parafilm and placed upright in 40tube racks in an incubator (model 818; Precision Scientific, Chicago). Cultures were maintained at $22^{\circ} \mathrm{C}$ and given a 12 -h photoperiod with a photosynthetic photon flux (PPF) of 30 to $44 \mu \mathrm{mol} \cdot \mathrm{m}^{-2} \cdot \mathrm{s}^{-1}$ provided by two $40-\mathrm{W}$ broad-spectrum fluorescent lamps (Verilux, Greenwich, Conn.). PPF was measured with a quantum sensor (LI-190SA; LI-COR, Lincoln, Neb.).

Preanthesis flower buds were removed from four plants of $V$. bracteata 'Lemon Flame'. Treatment and culture of flower buds was identical to that for leaf explants, except no running-water rinse was used, and explant orientation (abaxial or adaxial) was not monitored. Explants consisted of intact flower buds 7 to $15 \mathrm{~mm}$ long.

After 10 to 12 weeks of culture, explants exhibiting a morphogenetic response (roots, preshoots, or callus) were placed either intact or split in half before placement on an identical fresh medium. There were 24 to 40 explants per treatment after placement. After another 10 to 13 weeks of culture, explants with normal-appearing shoots were combined from all treatments for each genotype and explant source. They were placed on fresh medium with $8.87 \mu \mathrm{M}$ BA plus 5.4 $\mu \mathrm{M}$ NAA for the $V$. bracteata cultivars and on fresh medium with $8.87 \mu \mathrm{M}$ BA plus $0.54 \mu \mathrm{M}$ NAA for $V$. capensis. Subsequently, individual shoots or clusters of small shoots were excised and placed on fresh medium at 8- to 15 -week intervals for continued shoot multiplication. After the fourth culture sequence, shoots from the $V$. bracteata cultivars also were placed on medium with $8.87 \mu \mathrm{M}$ BA plus $0.54 \mu \mathrm{M}$ NAA. Shoots derived from the two explant sources for $V$. bracteata 'Lemon Flame' (leaves and flower buds) appeared identical and were combined for further shoot multiplication.

The shoot initiation and multiplication study was conducted once due to the limited availability of explant material. For shoot initiation, 40 explants, either leaf tissue or flower buds, were placed on each of the five treatments for each genotype. Percentage of morphogenetic response for the first culture period and the percentage of shoot initiation response for the second, third, and fourth culture periods were collected. The number of shoots per explant was not determined as it 
was not possible to accurately count the number of shoots in each culture tube without sacrificing the material. The medium selected for subsequent shoot multiplication was based on percent shoot initiation and on visual observation of the initiation medium that yielded the most normal-appearing shoots for each genotype.

In 1993, nonrooted shoots 2 to $10 \mathrm{~cm}$ tall of $V$. bracteata 'Rosalba' were individually cultured on MS medium supplemented with sucrose at $30 \mathrm{~g} \cdot \mathrm{L}^{-1}$ and 0.0 or $4.46 \mu \mathrm{M} \mathrm{K}-\mathrm{NAA}$. In 1994 , nonrooted shoots 2 to $10 \mathrm{~cm}$ tall of $V$. bracteata 'Lemon Flame' and nonrooted shoots 2 to $5 \mathrm{~cm}$ tall of $V$. capensis were individually cultured on the same medium supplemented with $0.0,4.14$, or $8.29 \mu \mathrm{M} \mathrm{K-IBA,} \mathrm{or} \mathrm{0.0,} \mathrm{4.46,}$ or $8.92 \mu \mathrm{M}$ K-NAA. Rooting percentage was recorded after 11 to 12 weeks. Shoots with at least one root $\geq 1.0 \mathrm{~cm}$ were recorded as rooted. Rooted shoots of $V$. bracteata 'Rosalba' were removed from tissue culture in either Nov. 1993 or Jan. 1994, while rooted shoots of $V$. bracteata 'Lemon Flame' and V. capensis were removed from tissue culture in Oct. 1994. Rooted shoots were rinsed free of medium, and transferred to the greenhouse for acclimatization. Shoots were planted in 36-cell plug trays, each cell containing $\approx 160 \mathrm{~cm}^{3}$ medium of nonsterilized 3 sand : 1 peat $(\mathrm{v} / \mathrm{v})$. Trays were covered with clear plastic domes, then placed under $50 \%$ shadecloth in the greenhouse. The plastic domes were propped up $\approx 3$ $\mathrm{cm}$ on one side after 2 to 3 weeks and completely removed after 3 to 4 weeks. Shoot survival was recorded 10 to 12 weeks after the shoots were removed from tissue culture.

The rooting study was conducted once. For $V$. bracteata 'Rosalba' 180 nonrooted shoots were placed on to the medium without KNAA and 100 shoots on to the medium with KNAA. For $V$. bracteata 'Lemon Flame' and $V$. capensis, 40 to 60 nonrooted shoots were used for each treatment. Rooting percentages were analyzed with the $\mathrm{G}$ statistic comparing the individual auxin treatments to the control. Differences in survival percentages between treatments were analyzed with Chi-square.

\section{Results and Discussion}

The procedure for surface-disinfection appeared optimum for the $V$. bracteata cultivars. Most of the flower bud and leaf explants (96\%; 574 of 600) were noncontaminated and appeared to be living after 8 weeks of culture. Conversely, only 77\% (154 of 200) of the $V$. capensis explants were noncontaminated and appeared to be living after 8 weeks of culture. The lower explant survival percentage for $V$. capensis was due to explant bleaching and death from the sodium hypochlorite treatment and was not due to contamination. Therefore, it appears necessary either to decrease the concentration of the sodium hypochlorite solution or to shorten the time in the disinfecting solution for optimum $V$. capensis explant survival.

Morphogenetic response of the explants after 10 to 12 weeks of culture ranged from $0 \%$ to $67 \%$, depending on the genotype, explant

Table 1. Auxin effects on the rooting of Veltheimia bracteata 'Lemon Flame', V. bracteata 'Rosalba', and $V$. capensis recorded after 11 to 12 weeks of culture on rooting medium, and their subsequent shoot survival in the greenhouse.

\begin{tabular}{|c|c|c|c|c|c|c|c|}
\hline & & \multicolumn{6}{|c|}{ Species tested } \\
\hline & & \multicolumn{4}{|c|}{ V. bracteata } & \multirow{2}{*}{\multicolumn{2}{|c|}{ V. capensis }} \\
\hline & & \multicolumn{2}{|c|}{ Lemon Flame } & \multicolumn{2}{|c|}{ Rosalba } & & \\
\hline \multicolumn{2}{|c|}{ Auxin $(\mu \mathrm{M})$} & $\overline{\text { Rooting }^{2}}$ & $\overline{\text { Survivaly }^{y}}$ & Rooting & Survival & \multirow{2}{*}{$\begin{array}{c}\text { Rooting } \\
(\%)\end{array}$} & \multirow{2}{*}{$\begin{array}{c}\text { Surviva } \\
(\%)\end{array}$} \\
\hline K-IBA & K-NAA & $(\%)$ & $(\%)$ & $(\%)$ & $(\%)$ & & \\
\hline 0.0 & 0.0 & 66 & 83 & 51 & 66 & 65 & 64 \\
\hline 4.14 & 0.0 & $95^{* *}$ & 63 & --- & --- & $84^{*}$ & 100 \\
\hline 8.29 & 0.0 & $96^{* *}$ & 63 & --- & --- & $93^{* *}$ & 85 \\
\hline 0.0 & 4.46 & $98^{* *}$ & 77 & $95^{* *}$ & 65 & $98^{* *}$ & 79 \\
\hline 0.0 & 8.92 & $86^{*}$ & 65 & --- & --- & $96^{* *}$ & 83 \\
\hline
\end{tabular}

${ }^{2}$ Significance of rooting percent within each species is based on the comparison of individual auxin treatments with the control (no hormone) using the G statistic.

${ }^{y}$ Survival percent within each species was not significantly different at $P=0.05$ according to Chi-square test. Number of surviving shoots per treatment ranged from 26 to 60 .

**** Significant at $P \leq 0.05$ or 0.01 , respectively.

type, and PGR treatment; no clearly discernible shoots were evident on any of the explants. None of the explants on medium without PGRs exhibited a morphogenetic response and thus were discarded.

Shoot initiation became evident during the second culture period. Percentage of response ranged from $0 \%$ to $79 \%$, depending on the genotype, explant type, and growth regulator treatment. Maximum percentage of explants with shoot formation was $79 \%$ for $V$. bracteata 'Lemon Flame' flower bud explants on medium with $4.44 \mu \mathrm{M}$ BA plus $0.54 \mu \mathrm{M}$ NAA, $39 \%$ for $V$. bracteata 'Lemon Flame' leaf explants on medium with $8.87 \mu \mathrm{M}$ BA plus 5.4 $\mu \mathrm{M}$ NAA, and $54 \%$ for $V$. bracteata 'Rosalba' leaf explants on medium with $8.87 \mu \mathrm{MBA}$ plus $5.4 \mu \mathrm{M}$ NAA.

Many of the shoots for the $V$. bracteata explants exhibited deformed leaf morphology, vitrification, or callus production. The best overall medium for normal-appearing shoots was with $8.87 \mu \mathrm{M}$ BA plus $5.4 \mu \mathrm{M}$ NAA; hence, the selection of this medium for subsequent culture sequences. By selecting only normal appearing shoots for subculture, $87 \%$ or more of the subcultured shoots exhibited normal morphology by the end of the fourth culture sequence. Upon subculturing shoots to medium with $8.87 \mu \mathrm{M}$ BA plus $0.54 \mu \mathrm{M}$ NA after the fourth culture sequence, there was a marked decrease in callus production with no apparent diminution in shoot quality or proliferation.

For $V$. capensis, only one explant (out of 200) initiated shoots. This was during the second culture sequence on medium with 8.87 $\mu \mathrm{M}$ BA plus $0.54 \mu \mathrm{M}$ NAA; therefore, this medium was chosen for subsequent shoot multiplication. All shoots of $V$. capensis used in the rooting study were derived from this single initial explant. There was minimal or no callus production, and shoot morphologies were normal-appearing. Veltheimia capensis shoot multiplication and growth was markedly slower than for the $V$. bracteata cultivars, which is in agreement with the comparative growth rates of the two species from seed or divisions under greenhouse growing conditions.

Shoots of the three genotypes rooted on all rooting media. The four auxin treatments significantly increased rooting percentages in comparison to the control (no PGR) for the three genotypes (Table 1). Maximum percent rooting exceeded $95 \%$ for all three genotypes on medium with $4.46 \mu \mathrm{m}$ K-NAA. These rooting percentages are superior to those reported for tissue culture rooted shoots of the related genus Lachenalia (Ault, 1995; Klesser and Nel, 1976), and similar to those reported for the related genus Eucomis (Ault, 1985).

Survival of rooted shoots after removal from tissue culture did not differ significantly between the prior rooting treatments (Table 1). Percent survival was greater than $63 \%$ for all treatments. These survival percentages are overall lower than those reported for greenhouse acclimatization of tissue culture rooted Lachenalia shoots (Ault, 1995) and Eucomis shoots (Ault, 1995). However, these survival rates are similar to the $82 \%$ reported for Galtonia candicans (Drewes and van Staden, 1993), indicating the need for additional research to optimize shoot survival for Veltheimia tissue culture shoots.

By employing the appropriate combination of BA and NAA, it is possible to promote shoot initiation and multiplication, and shoot rooting in tissue culture from nonbulb tissue of $V$. bracteata and $V$. capensis. The use of explants from other than bulb tissue avoids the destruction of stock plants. An effective method for propagating selected Veltheimia genotypes should help enhance their horticultural appeal and commercial availability.

\section{Literature Cited}

Ault, J.R. 1995. In vitro rooting and greenhouse acclimatization of Lachenalia shoots. HortScience 30:13041305

Ault, J.R. 1995. In vitro propagation of Eucomis autumnalis, E. comosa, and E. zambesiaca by twin-scaling. HortScience 30:1441-1442

Doutt, R.L. 1994. Cape bulbs. Timber Press, Portland, Ore. Drewes, F.E. and J. van Staden. 1993. In vitro propagation of Galtonia species. S. Afr. J. Bot. 59:457-458.

Du Plessis, N. and G. Duncan. 1989. Bulbous plants of southern Africa. Tafelberg Publishers, Cape Town, South Africa.

Hussey, G. 1975. Propagation of hyacinths by tissue culture. Scientia Hort. 3:21-28.

Klesser, P.J. and D.D. Nel. 1976. Virus diseases and tissue culture of some South African bulbs. Acta Hort. 59:7176.

Murashige, T. and F. Skoog. 1962. A revised medium for rapid growth and bioassays with tobacco tissue cultures. Physiol. Plant. 15:473-479.

Nel, D.D. 1983. Rapid propagation of Lachenalia hybrids in vitro. S. Afr. J. Bot. 2(3):245-246. 